\title{
FINANCING DEVELOPMENT, FINANCING CONSTRAINT AND R\&D INVESTMENT OF STRATEGIC EMERGING INDUSTRIES IN CHINA
}

\author{
Ke XUD1, 2*, Chengxuan GENG $^{1}$, Xiaoshu WEI ${ }^{3}$, Huifeng JIANG(D2 \\ ${ }^{1}$ School of Economics and Management, Nanjing University of Aeronautics and Astronautics, \\ 211106 Nanjing, China \\ ${ }^{2}$ School of Economics and Management, Changzhou Institute of Technology, \\ 213032 Changzhou, China \\ ${ }^{3}$ School of Foreign Languages, Jiangsu University of Technology, 213001 Changzhou, China
}

Received 25 March 2019; accepted 26 February 2020

\begin{abstract}
Taking listed companies of strategic emerging industries as the research subject, this paper uses KZ index to measure the degrees of financing constraints and financial intermediary as well as the stock market to represent the level of financial development. Then empirical models are constructed to analyse whether financial development can alleviate the financing constraints of R\&D investment or not. Finally, the paper further investigates the interaction of financial development and firm characteristics (including firm size, ownership nature and establishment time) on the impact of R\&D investment. The results show that the degree of financing constraint is negatively correlated with R\&D investment. Both the development of financial intermediary and stock market play an important role in alleviating the R\&D financing constraints, and the development of the stock market can better alleviate the R\&D financing constraint. Moreover, the development of financial intermediary and stock market plays a heterogeneous role among enterprises of different size, nature and time of establishment. In order to achieve the 13th Five-year Plan target of strategic emerging industries in China, the government and enterprises need to work together to improve the financial development level and reduce information asymmetry, so as to expand the investment channels of R\&D investment and improve their innovation capability and competitiveness.
\end{abstract}

Keywords: financing development, financial intermediary, stock market, financing constraints, $\mathrm{KZ}$ index, R\&D investment, strategic emerging industries.

JEL Classification: G32, L25, M13, O16, O32.

\section{Introduction}

Strategic emerging industries are currently the key industries to be cultivated in China. In order to achieve the target put forward in the 13th Five-year Plan of China and enhance

*Corresponding author. E-mail: 18578410@qq.com 
the endogenous power of the development of strategic emerging industries, it is necessary to enhance the innovation ability. R\&D investment is the fundamental way to improve the innovation ability of strategic emerging industries, and it is of strategic significance to transform the pattern of economic development and enhance industrial competitiveness. Because the R\&D investment usually requires a large amount of capital with high risk and long return period, the $R \& D$ investment faces difficulties in financing. $R \& D$ investment mainly comes from internal fund and external financing. In the case of information asymmetry, external fund providers are at an information disadvantage and face high risks, so they require high returns. As a result, the cost of external financing is much higher than that of internal financing, which ultimately leads to financing constraints on R\&D investment.

As for the financing constraints faced by enterprises' R\&D investment, scholars at home and abroad have done a lot of researches and come to different conclusions. Fazzari et al. (1988) innovatively put forward the concept of financing constraint and analyze the influence of financing constraint on enterprise investment under the condition of imperfect capital market and asymmetric information. Brown, Martinsson, and Petersen (2011) believe that the nature of $R \& D$ makes it particularly vulnerable to financing. But there is little evidence that financing constraints limit European R\&D. They also argue that the stock market is important for R\&D in Europe. Lu, Zheng, and Li (2013) hold that there are financing constraints in the listed high-tech companies, which restrict $\mathrm{R} \& \mathrm{D}$ investment. R\&D funds mainly come from internal cash flow and stock financing. Guariglia and Liu (2014) find that innovation activities are limited by the availability of internal financing. The correlation degree of internal financing and innovation in private enterprises is the highest, while that degree in state-owned enterprises is the lowest. Cao (2014) insist that both internal and external financing constraints are important factors influencing enterprises' $R \& D$ investment, but the degree of dependence of $R \& D$ investment on internal and external financing varies significantly depending on different ownership types. Many scholars believe that enterprises generally have R\&D financing constraints. For examples, $\mathrm{Gu}$ and Zhai (2014) find that there is R\&D investment-cash flow sensitivity in the company. Some scholars conclude that there is a significant positive relationship between R\&D expenditure and internal cash flow (Sasidharan et al., 2015; Hu et al., 2017). Others find a significant negative correlation between financing constraints and enterprises' R\&D investment (Chen \& Yang, 2018; Zhang, 2018). There are also some scholars who have different opinions. Liu, He, and Zheng (2018) considers that there is a nonlinear relationship between financing constraints and R\&D investment, and when the financing constraints are high, the financing constraints are positively related to the $\mathrm{R} \& \mathrm{D}$ investment of the enterprise, and when the degree of financing constraints falls to a certain threshold, the financing constraints are negatively correlated with the R\&D investment of the enterprise. Cheng, Wang, and Liu (2019) argue that financing constraints do not reduce the R\&D participation of enterprises, but distorts the development and manipulation of enterprises.

In the research process, the foreign scholars have formed different methods to measure financing constraints. Fazzari et al. (1988) use the sensitivity of investment to cash flow as the measurement of financing constraint. Kaplan and Zingales (1997) put forward a chal- 
lenge to the above viewpoint, and hold that high investment-cash flow sensitivity cannot be used as evidence of financing constraint. Lamont, Polk, and Saaárequejo (2001) construct KZ index based on Kaplan and Zingales (1997). Cleary (1999) constructs financing constraint index using multiple discriminant analysis. Whited and Wu (2006) establish the WW index of external financing constraint based on generalized moment method of investing Euler equation. Almeida, Campello, and Weisbach (2004) analyze the influence of financing constraints on corporate policies based on cash-cash flow sensitivity model. It is believed that companies subjected to financing constraints have positive cash-cash flow sensitivity. Farre-Mensa and Ljungqvist (2016) evaluate how well five popular measures (paying dividends, having a credit rating, and the Kaplan-Zingales, Whited-Wu, and Hadlock-Pierce indices) identify firms that are financially constrained, and they conclude that none of the five measures can well identify the enterprises subject to financing constraints. On the basis of foreign literates, domestic scholars modified these indexes to measure the degree of financing constraint of Chinese enterprises, of which KZ index (Wei et al., 2014), investment-cash flow sensitivity (Wei \& Liu, 2004; Kuang, 2011; Zhai \& Gu, 2013; Zeng et al., 2017; Chen \& Chang, 2019), cash-cash flow sensitivity (Geng et al., 2018), SA index (Hu et al., 2018) and comprehensive index (Zhang, 2018) are popular.

The degree of financing constraint is closely related to the level of financial development in the region where enterprises are located. Love (2003) analyzes the relationship between financial development and financing constraints based on Euler's investment equation. The results show that the development level of financial market is negatively correlated with the sensitivity of investment and the availability of internal funds. Laeven (2003) analyzes whether financial liberalization has eased the financing restrictions of companies, and indicates that with the progress of financial liberalization, financing restrictions of small businesses are eased, while that of large companies are increased. Wei, Zeng, and Li (2014) believe that the more advanced the financial ecology and its constituent elements are, the less financing constraint companies will face. A good financial environment is more conducive to easing financing constraints of SMEs and private enterprises. And a good financial ecological environment can enable enterprises to obtain more bank loans and commercial credit to ease financing constraints. Zeng, Wang, and Zhang (2017) analyze the influence of financial development on the financing constraint of China's small and medium-sized listed companies, and conclude that financial development can alleviate the financing constraint. Alam, Uddin, and Yazdifar (2019) find that a country's financial system influences the choice of available sources of finance. Firms from countries that follow a bank - based financial system tend to rely on external funds while firms from countries that follow a market-based financial system depend more on internal funds for financing R\&D investments.

With the deepening of China's market-oriented reform, the financing constraints of enterprises' R\&D investment and the role played by financial development have attracted the attention of domestic scholars. Most scholars agree that the improvement of financial development can alleviate the degree of financing constraints. Moreover, compared with large, state-owned or old enterprises, the positive influence of financial development on enterprise $R \& D$ investment is more obvious in small, private or young enterprises (Hall \& 
Lerner, 2010; Xie \& Fang, 2011; Wei et al., 2014; Dai \& Cheng, 2015; Zhang \& Wang, 2016; Hu et al., 2017; Song et al., 2018; Wei \& Lan, 2019). But there is no unanimous conclusion on whether financial intermediaries or stock markets can more effectively ease financing constraints. Some scholars believe that the development of financial intermediary plays a more important role in alleviating financing constraint (Zhai \& Gu, 2013; Yuan \& Xu, 2019), while others believe that the stock market plays a more significant role (Hu \& Qin, 2013; Zhu \& Sun, 2015; Zhang \& Wang, 2016).

Findings of most of the studies focused on financing constraints and R\&D investment revealed the financing constraints do exist in the enterprises' $R \& D$ investment in China (Wei \& Liu, 2004; Lu et al., 2013; Gu \& Zhai, 2014; Wan, 2018). And as an important external condition of enterprises' R\&D investment, financial ecological environment has attracted some scholars' attention. Most scholars agree that a good financial environment or financial development of financial deepening is conducive to easing the financing constraints of R\&D investment (Lu et al., 2013; Wei et al., 2014; Zhang \& Wang, 2016; Liu et al., 2018; Wei \& Lan, 2019). However, there is no unanimous conclusion whether financial intermediaries or stock markets can more effectively ease financing constraints.

The purpose of this study is to analyze the impact of financing constraints on R\&D investment of listed companies in China's strategic emerging industries, and to analyze whether financial development can alleviate the financing constraints or not. The interaction of financial development and firm characteristics on the impact of $R \& D$ investment is further analyzed in order to provide intellectual support to increase R\&D investment and promote innovation capability in strategic emerging industries. First, different from the existing researches on small and medium-sized enterprises or high-tech enterprises, this paper takes strategic emerging industries as the research subject and lays a theoretical foundation for the development of strategic emerging industries. Strategic emerging industries are currently the key industries to be cultivated in China. They represent the direction of a new round of scientific and technological revolution and industrial transformation. As an industry with significant technology-intensive characteristics, R\&D investment is of great significance to the cultivation of core industrial competitiveness and sustainable industrial development. Second, there is no consensus on whether the financial intermediary or the stock market plays a more obvious role in alleviating financing constraint of $\mathrm{R} \& \mathrm{D}$ investment in the existing research. Moreover, few scholars have studied the interaction of the financial development and firm characteristics (including firm size, ownership nature and establishment time) on the impact of $R \& D$ investment. This study enriches the research in these aspects.

The remainder of this paper is organized as follows. In Section 1, we present a theoretical analysis that explains the relationship among financing development, financing constraint and R\&D investment. In Section 2, we describe the index, method and samples used in the study. In Section 3, we discuss the results of empirical research. In the last section we summarize our main findings. 


\section{Theoretical frameworks}

\subsection{Theoretical basis}

\subsubsection{Information asymmetry theory}

In the market, different people have different levels of information, and those who have a comprehensive understanding of the information are in a favorable position in the market transaction and decision-making. Information asymmetry can lead to moral hazard and adverse selection. Adverse selection increases the risk of a loan. In order to avoid risks, lenders may not extend loans to customers with bad credit. In terms of enterprise financing, if the market information is not symmetrical and the communication is not smooth, it is difficult for external investors to fully know the enterprise's operating status, risks, profits and other important information. External financing will generate transaction costs for enterprises, thus raising the financing threshold for enterprises and reducing the intention of enterprises to rely on external financing for investment.

\subsubsection{Financing constraint theory}

Modigliani and Miller (1958) propose that under the assumption of complete capital market, the investment decision of an enterprise is not related to its financing decision. In general, an investment in a project is only considered if the net present value of its cash flow exceeds the relevant capital expenditure. In a complete capital market, companies can often raise exogenous capital at the same cost as endogenous capital, so they do not face financing constraints.

However, information asymmetry is ubiquitous in reality. Fazzari et al. (1988) put forward the financing constraint hypothesis according to the information asymmetry theory. Due to information asymmetry, more transaction costs and information costs will occur in the company. As a result, the company's overall financing costs will be passively increased, and the external financing operation of the company will be subject to certain restrictions. In the end, enterprises will inevitably rely on internal cash flow to a large extent in their investment activities. When the difference between endogenous financing cost and exogenous financing cost keeps expanding, the financing constraint will become more obvious, and the dependence of the company's investment operation on internal cash flow will also become more obvious, so there will be a significant positive correlation between the amount of investment and the amount of cash flow.

\subsubsection{Financial development theory}

Financial development theory studies the relationship between financial development and economic growth, namely roles of the financial intermediary and financial market in economic development. Moreover, it studies how to establish an effective financial system and financial policy combination to maximize the economic growth and how to make rational use of financial resources to achieve sustainable financial development and eventually realize the sustainable development of economy.

According to the above theories, we know that information asymmetry generally exists in reality. $\mathrm{R} \& \mathrm{D}$ investment has financing constraints and even faces more serious external 
financing difficulties than general investment, and financial development can alleviate financing constraints. But for China's strategic emerging industries, the following issues remain to be further studied. The first is whether there are R\&D financing constraints in strategic emerging industries. The second is whether the developments of financial intermediaries and the stock market can reduce the financing constraints of R\&D investment. If yes, which of the two plays a more effective role? The third is whether financial intermediation and stock market play the same role in enterprises of different size, nature and time of establishment.

\subsection{Development status of strategic emerging industries}

Strategic emerging industries represent the direction of a new round of scientific and technological revolution and industrial transformation, and they are key areas for China to foster new growth drivers and gain new competitive advantages. A circular issued by China's national bureau of statistics in 2018 mentioned that strategic emerging industries are based on major technological breakthroughs and major development needs and play a leading role in overall and long-term economic and social development. They are industries with intensive knowledge and technology, low consumption of material resources, great growth potential and good comprehensive benefits. It covers nine major fields, including new generation of information technology industry, high-end equipment manufacturing industry, new materials industry, biological industry, new energy automobile industry, new energy industry, energy conservation and environmental protection industry, digital creative industry and related services.

Since the official document "The Decision of the State Council on Accelerating Fostering and Development of Strategic Emerging Industries" issued in 2010, the strategic emerging industries have been developing continuously. At the end of 2010, the added value of strategic emerging industries accounted for about 4\% of China's GDP and by the end of 2020, it will reach $15 \%$. As innovative is the basis and one of the fundamental characteristics of the development of strategic emerging industries, the research on the R\&D investment of enterprises has become an important subject in economic and industrial development. The national and local governments have adopted multiple measures to promote the development of strategic emerging industries, including setting up special financial funds, guiding banks to provide credit loan support, guiding guarantee institutions to provide guaranteed loan support, giving tax incentives and so on. According to data from the State Information Center, by the first half of 2018, the number of A-share listed companies in strategic emerging industries had accounted for $42.4 \%$ of the total. Revenue growth was $85.3 \%$ higher than the overall growth rate, the R\&D investment intensity was $44.7 \%$ higher than the overall growth rate, and profit margin was $12 \%$ higher than the overall growth rate. Although the development speed and the R\&D investment intensity of strategic emerging industries are higher than the overall level of listed companies, there is still a gap between China's R\&D intensity and that of the world's advanced countries. According to the latest disclosure, the intensity of R\&D expenditure in China reached 2.19\% in 2018, while South Korea 4.32\%, Japan 3.5\%, the United States and Germany 2.84\%, Canada 2.34\% and France 2.25\%. Therefore, it is of great significance to improve R\&D investment intensity and industrial competitiveness of 
strategic emerging industries to support economic development, industrial transformation, and innovation-oriented country construction.

\subsection{The theoretical analysis of the relationship among financial development, financing constraints, and $R \& D$ investment}

\subsubsection{Financing constraint and $R \& D$ investment}

Financing constraint refers to the difficulty of obtaining funds from outside when enterprises are faced with better investment opportunities. Due to the existence of information asymmetry, external fund providers are at the disadvantage of information and face high return rate due to high risks, which makes the external financing cost higher than the internal financing cost and finally leads to financing constraints. R\&D investment refers to the expenses in the research and development of products, technologies, materials, processes and standards which are required to be disclosed in the financial statements of enterprises.

$\mathrm{R} \& \mathrm{D}$ investment requires a large amount of capital which is difficult to be obtained by internal funding, and moreover there is high risk and long payback period of R\&D investment, thus $R \& D$ investment faces great difficulties in external financing. If sufficient funds are not available, investment in $\mathrm{R} \& \mathrm{D}$ will be limited. Therefore, it is believed that financing constraints will restrict enterprises' $\mathrm{R} \& \mathrm{D}$ investment.

According to the information asymmetry theory, due to the ubiquitous information asymmetry, external fund providers are at an information disadvantage and face high risks, so they require high returns. As a result, external financing costs are much higher than internal financing costs, and R\&D investment mainly depends on internal cash flow (Hu et al., 2017). If the enterprise's internal cash flow is insufficient, it will restrict the enterprise's R\&D activities. Many scholars' researches indicate that financing constraints have a negative impact on R\&D investment (Lu et al., 2013; Cao, 2014; Chen \& Yang, 2018; Zhang, 2018).

Our views are consistent with the above analysis, and thus hypothesis 1 is proposed.

Hypothesis 1: Financing constraint is negatively correlated with enterprises' R\&D investment.

\subsubsection{Financial development and $R \& D$ investment}

Financial development is the continuous improvement of financial efficiency brought by the expansion of financial transaction scale and the upgrading of financial industry. This is usually reflected in the development of financial intermediaries and capital markets. The developed financial intermediary and capital market can reduce the market incompleteness, so as to narrow the cost difference between internal financing and external financing, and alleviate the financing constraint of enterprises' R\&D investment.

The theory of financial development gives a good explanation of the role and mechanism of financial intermediation and capital market in promoting economic growth. At the same time, combining with the theory of information asymmetry, we can find that the financial intermediaries such as banks can reduce moral risks and adverse selection problems caused by information asymmetry when the enterprise raises external financing. Because the banks keep close contact with the enterprise and have more financial informa- 
tion of the enterprise, they can obtain a deeper understanding of enterprises at a low cost. Therefore, the development of financial intermediary plays an important role in alleviating the financing constraints and the enterprises can meet the needs of R\&D investment by bank loans.

Similarly, with the development of China's stock market, especially the establishment of SMEs Board and Growth Enterprises Market Board, a good equity financing environment has been provided for strategic emerging industries. Moreover, financing in the capital market has strict requirements on information disclosure, which greatly reduces the problem of information asymmetry. Therefore, the development of stock market also plays an important role in alleviating the financing constraints and the enterprises can raise sufficient funds for R\&D activities.

Scholars at home and abroad have no objection that financial development can ease financing constraints and promote enterprise $R \& D$ investment, but opinions differ on the roles of financial intermediaries and stock market. Some argue that financial intermediation plays a more important role (Zhai \& Gu, 2013; Yuan \& Xu, 2019), while others argue that stock markets can supply with more funds and ease financing constraints more efficiently (Hu \& Qin, 2013; Zhu \& Sun, 2015; Zhang \& Wang, 2016; Liu et al., 2018; Wei \& Lan, 2019).

We hold the opinion that the development of financial intermediaries and capital markets can alleviate the financing constraints of $R \& D$ investment in strategic emerging industry, but due to the high risk of R\&D investment, bank loans and other debt financing channels have strict requirements and high costs. The capital market provides an important financing channel and plays a more important role in promoting enterprises' R\&D investment. Therefore, hypothesis 2 is proposed.

Hypothesis 2: The development of financing intermediaries and capital market are positively correlated with enterprises' R\&D investment, and the capital market plays a more important role compared to financing intermediaries.

\subsubsection{The influence of financial development on $R \& D$ investment: based on different perspective}

From the perspective of the firm size, compared with large enterprises, small enterprises are weak in profitability, insufficient in internal cash flow and face higher financing constraints. Therefore, banks are reluctant to provide loans to small enterprises because of the high rate of failure and default. As for the capital market, although there are SMEs Board and GEM Board, few companies can go public to raise capital. So most small enterprises have trouble in financing and face stronger financing constraints in $R \& D$ investment.

From the perspective of the firm nature, the intervention or guidance of the government still has some influence on the market economy in China, so state-owned enterprises face lower financing constraints than non-state-owned enterprises. Consistent with the analysis of small enterprises, private enterprises also have difficulty in financing.

From the perspective of the establishment time, enterprises with long establishment time have established long-term cooperative relations with banks and their development is relatively stable, so they are less affected by financing constraints. 
According to the information asymmetry theory and financing constraint theory, due to the existence of information asymmetry, enterprises' R\&D investment is often faced with financing constraints. The small enterprises or non-state-owned enterprises or enterprises of short establishment time have high financing constraints because they are faced with serious information asymmetry and not favored by banks. Most of these companies do not meet the listing requirements, so it is difficult for them to obtain funds from capital markets. Financial development has a greater impact on these enterprises, which can reduce the degree of information asymmetry, ease financing constraints and promote investment in $\mathrm{R} \& \mathrm{D}$ investment.

Some scholars have studied the heterogeneity of the effects of financial development on enterprises with different characteristics. Fazzari et al. (1988) find that the impact of financing constraints on enterprise investment is different in different types of enterprises. A sound financial environment is more conducive to ease the financing constraints of SMEs and private enterprises (Xie \& Fang, 2011; Wei et al., 2014; Dai \& Cheng, 2015; Wu, 2019; Wei \& Lan, 2019). Liu (2014) concludes that the easing effect of financial development on financing constraints is most significant in East China and weakest in West China. Sasidharan, Lukose, and Komera (2015) find that enterprises' R\&D investment mainly relies on internal cash flow, especially for small and young companies.

On the basis of previous analysis, we believe that compared with large, state-owned and old enterprises, financial development plays a more significant role in easing financing constraints of small, non-state-owned and newly established enterprises. Therefore, hypothesis 3 is proposed.

Hypothesis 3: Financial development plays a more significant role in alleviating R\&D financing constraints of small, non-state-owned or new enterprises.

\section{Data and methodology}

\subsection{Data and sample selection}

This paper selects 200 strategic emerging industry companies from Shenzhen strategic emerging industry index (index code 399641) disclosed by Shenzhen stock exchange as samples. The study period is 2010-2018. Because the strategic emerging industries have been developing continuously since the official document "The Decision of the State Council on Accelerating Fostering and Development of Strategic Emerging Industries" issued in 2010. The following samples were removed before analysis: (1) Listed company in Tibet is eliminated due to incomplete data on the financial development of Tibet. (2) Samples of zero or undisclosed $R \& D$ investment were excluded. (3) Some companies are eliminated due to incomplete financial data during 2010-2018. Finally, a total of 1371 sample data are obtained as shown in Table 1 . Data such as R\&D data and financial indicators came from the CSMAR database, and data of financial development came from the statistical yearbook.

It can be clearly seen from Table 1 that strategic emerging industries have made great progress since 2010. With the Chinese government's emphasis on $\mathrm{R} \& \mathrm{D}$ and support for 
Table 1. Sample distribution

\begin{tabular}{|c|c|c|c|}
\hline Year & $\begin{array}{c}\text { Sample size(Includes samples } \\
\text { with zero or undisclosed } \\
\text { R\&D investment) }\end{array}$ & $\begin{array}{c}\text { Sample size(Exclude samples } \\
\text { with zero or undisclosed } \\
\text { R\&D investment) }\end{array}$ & $\begin{array}{c}\text { Average ratio of R\&D } \\
\text { investment to operating } \\
\text { income (\%) }\end{array}$ \\
\hline 2010 & 98 & 45 & 6.92 \\
\hline 2011 & 150 & 88 & 8.37 \\
\hline 2012 & 173 & 158 & 7.60 \\
\hline 2013 & 176 & 165 & 7.88 \\
\hline 2014 & 178 & 170 & 7.53 \\
\hline 2015 & 186 & 181 & 7.07 \\
\hline 2016 & 186 & 181 & 7.65 \\
\hline 2017 & 191 & 187 & 8.15 \\
\hline 2018 & 199 & 196 & 8.54 \\
\hline Total & 1537 & 1371 & 7.80 \\
\hline
\end{tabular}

strategic emerging industries, $\mathrm{R} \& \mathrm{D}$ investment in strategic emerging industries has been strengthened. In 2010, less than half of the sample enterprises had R\&D investment. Yet, by $2018,98.49 \%$ of the sample enterprises had R\&D investment. Besides, the intensity of $\mathrm{R} \& \mathrm{D}$ investment is also increasing. The average ratio of $\mathrm{R} \& \mathrm{D}$ investment to operating income rose from $6.92 \%$ in 2010 to $8.54 \%$ in 2018 . According to the data disclosed at the second Strategic Emerging Industries Development Summit, in the recent five years, the R\&D investment intensity of listed companies in strategic emerging industries is about $50 \%$ higher than that of listed companies in general.

\subsection{Variable definition}

\subsubsection{Dependent variable}

Take R\&D investment intensity as dependent variable. Compared with the total R\&D investment index, the R\&D investment intensity can better reflect the R\&D input of different enterprise scale, and it is more comparable among different enterprises. However, R\&D investment intensity varies greatly among different enterprises. As we can see from Table 2, R\&D investment intensity of 1061 sample companies is distributed between 0 and $10 \%$, accounting for $77.39 \%$ of the total sample. Therefore, we take the natural logarithm of the R\&D investment intensity as the dependent variable. Thus, the nature and correlation of the data will not be changed, and the data will become more stable and the collinearity and heteroscedasticity of the model will be weakened.

\subsubsection{Independent variables}

Financial development level: Liu (2007), Li and Zhang (2009), Liu and Chen (2011) analyze the index of financial ecological environment in different regions of China which is composed of government governance, economic foundation, financial development and system and credit culture. Many scholars take the development of financial market as an indicator 
Table 2. The frequency distribution of R\&D investment to operating income

\begin{tabular}{|c|c|}
\hline $\mathrm{R} \& \mathrm{D}$ investment intensity & Sample size \\
\hline $0-5 \%$ & 645 \\
\hline 5-10\% (include 5\%) & 416 \\
\hline 10-15\% (include 10\%) & 153 \\
\hline 15-20\% (include 15\%) & 62 \\
\hline $20-25 \%$ (include 20\%) & 36 \\
\hline 25-30\% (include 25\%) & 23 \\
\hline 30-35\% (include 30\%) & 5 \\
\hline $35-40 \%$ (include $35 \%$ ) & 11 \\
\hline $40-45 \%$ (include $40 \%$ ) & 7 \\
\hline $45-50 \%$ (include $45 \%$ ) & 7 \\
\hline $50-55 \%$ (include $50 \%$ ) & 4 \\
\hline $55-60 \%$ (include $55 \%$ ) & 2 \\
\hline
\end{tabular}

to measure the financial development, as emphasized in the report "Marketization Index of Provinces in China" compiled by Wang, Fan, and Yu (2017). However, because the disclosure of these indexes is lagging behind, the latest disclosure only reveals the financial development level in 2014. Therefore, this paper uses the balance of loans of financial institutions / GDP (FIN1) and the amount raised by issuing A shares during a certain year / GDP (FIN2) as the proxy variable for financial development, which reflect financial intermediary development and stock market development.

Financial constraints (FC): The scholars at home and abroad have formed several methods to measure financing constraints. It is widely used in academic research to construct a comprehensive index to measure the degree of corporate financing constraint by combining several indicators that can reflect the degree of financing constraint. This paper uses the KZ index to calculate the financing constraint index (Kaplan \& Zingales, 1997; Lamont, Polk, \& Saaárequejo, 2001; Wei et al., 2014), because the construction of KZ index makes use of a large amount of qualitative and quantitative information, which is more reliable than using pre-classification variables to group enterprises. In addition, $\mathrm{KZ}$ index can be used to obtain the specific value of financing constraint degree of listed companies, which is convenient to compare different listed companies and different years in strategic emerging industries.

This paper takes five factors including net operating cash flow, cash dividends, cash holdings, ratio of liabilities to assets and Tobin's $Q$ to build a comprehensive index to measure the degree of financing constraint. The calculation steps are as follows: (1) $\mathrm{CF}_{\mathrm{it}} / \mathrm{A}_{\mathrm{it}-1}, \mathrm{DIV}_{\mathrm{it}} /$ $A_{i t-1}, C_{i t} / A_{i t-1}, L V_{i t}, Q_{i t}$ were calculated respectively. Then arrange the financial indicators of all samples in order, if $\mathrm{CF}_{\mathrm{it}} / \mathrm{A}_{\mathrm{it}-1}, \mathrm{DIV}_{\mathrm{it}} / \mathrm{A}_{\mathrm{it}-1}, \mathrm{C}_{\mathrm{it}} / \mathrm{A}_{\mathrm{it}-1}$ are less than the median, $\mathrm{KZ}_{1}, \mathrm{KZ}_{2}$, $\mathrm{KZ}_{3}$ is 1 and vice versa, and if $\mathrm{LEV}_{\mathrm{it}}, \mathrm{Q}_{\mathrm{it}}$ are greater than the median, $\mathrm{KZ}_{4}, \mathrm{KZ}_{5}$ takes 1 and vice versa. (2) Calculate $K Z=K Z_{1}+K_{2}+K Z_{3}+K_{4}+K Z_{5}$, so as to get the $K Z$ value of each enterprise. (3) $\mathrm{KZ}$ is taken as the dependent variable, and the other five variables as the independent variables to carry out ordered logistic regression to obtain the regression coefficient. (4) The KZ index of each listed company is calculated according to the model results. 


\subsubsection{Control variables}

On the basis of referring to a large number of literatures, firm size, capital intensity, profitability, investment opportunity, the nature of the firm and establishment time are introduced to explain the differences in enterprise $R \& D$ investment. In addition, the year is controlled for regression. The variable definition and calculation method is shown in Table 3.

Table 3. Variable definition and calculation method

\begin{tabular}{|c|c|c|c|}
\hline $\begin{array}{l}\text { Type of } \\
\text { Variables }\end{array}$ & $\begin{array}{l}\text { Name of } \\
\text { Variables }\end{array}$ & Symbol & Calculate formula \\
\hline $\begin{array}{l}\text { Dependent } \\
\text { Variable }\end{array}$ & $\begin{array}{l}\text { R\&D } \\
\text { investment } \\
\text { intensity }\end{array}$ & $\mathrm{RD}$ & LN(R\&D investment / Operating revenue) \\
\hline \multirow{3}{*}{$\begin{array}{l}\text { Independent } \\
\text { Variables }\end{array}$} & \multirow{2}{*}{$\begin{array}{l}\text { Financial } \\
\text { development } \\
\text { level }\end{array}$} & FIN1 & The balance of loans of financial institutions / GDP \\
\hline & & FIN2 & $\begin{array}{l}\text { The amount raised by issuing A shares during a certain } \\
\text { year / GDP }\end{array}$ \\
\hline & $\begin{array}{l}\text { Financing } \\
\text { Constraint }\end{array}$ & FC & $\begin{array}{l}\text { The financing constraint index is constructed by several } \\
\text { variables according to Kaplan and Zingales (1997); } \\
\text { Lamont, Polk, and Saaárequejo (2001); Wei, Zeng, and } \\
\text { Li (2014) }\end{array}$ \\
\hline \multirow{8}{*}{$\begin{array}{l}\text { Control } \\
\text { Variables }\end{array}$} & Firm Size & SIZE & LN ( total assets) \\
\hline & $\begin{array}{l}\text { Capital } \\
\text { Intensity }\end{array}$ & CAP & LN (Net fixed asset value / the number of employees) \\
\hline & Profitability & ROA & Net profit / Average balance of assets \\
\hline & $\begin{array}{l}\text { Investment } \\
\text { Opportunity }\end{array}$ & Q & Tobin's Q = Market value / Replacement value \\
\hline & Growth rate & GROWTH & $\begin{array}{l}\text { (Operating income of the current year - operating } \\
\text { income of the previous year)/ Operating income of the } \\
\text { previous year }\end{array}$ \\
\hline & $\begin{array}{l}\text { The nature of } \\
\text { the firm }\end{array}$ & NAT & State - owned, 1; Non-state-owned, 0 \\
\hline & $\begin{array}{l}\text { Establishment } \\
\text { time }\end{array}$ & AGE & The year of study - the year of establishment \\
\hline & YEAR & YEAR & Set the virtual variable base on 2010 \\
\hline \multirow{6}{*}{$\begin{array}{l}\text { Other } \\
\text { Variables }\end{array}$} & $\begin{array}{l}\text { Net operating } \\
\text { cash flow }\end{array}$ & $\mathrm{CF}$ & Operating cash inflow - Operating cash outflow \\
\hline & $\begin{array}{l}\text { Cash } \\
\text { dividends }\end{array}$ & DIV & The distribution of dividends or profits \\
\hline & $\begin{array}{l}\text { Cash } \\
\text { holdings }\end{array}$ & $\mathrm{C}$ & The balance of cash and cash equivalents \\
\hline & $\begin{array}{l}\text { Ratio of } \\
\text { liabilities to } \\
\text { assets }\end{array}$ & LEV & Total liabilities / Total assets \\
\hline & Tobin's Q & Q & Tobin’s Q = Market value / Replacement value \\
\hline & Total assets & $\mathrm{A}$ & Total assets \\
\hline
\end{tabular}




\subsection{Empirical model}

In this paper, the following multiple regression models are constructed based on the existing literature to analyze the influence of financial development and financing constraints on the $\mathrm{R} \& \mathrm{D}$ investment of listed companies in strategic emerging industries.

$$
R D_{i t}=\beta_{0}+\beta_{1} F C_{i t}+\beta_{2} \text { Control }_{i t}+\varepsilon_{i t} .(\text { Model 1) }
$$

In the formula, $\mathrm{i}$ is the enterprise individual, $\mathrm{t}$ is the time, FC stands for financing constraints variable, Control stands for control variables including SIZE, CAP, ROA, Q, GROWTH, NAT and AGE. Model 1 is used to verify Hypothesis 1.

Model 2 adds financial development variables on the basis of Model 1.

$$
R D_{i t}=\beta_{0}+\beta_{1} \text { FIN }_{i t}+\beta_{2} F C_{i t}+\beta_{3} \text { Control }_{i t}+\varepsilon_{i t} \text {. (Model 2) }
$$

FIN represented here in two variables FIN1 and FIN2, which represent the development of financial intermediaries and the development of stock markets. Other variable definitions are consistent with Model 1. Model 2 is used to verify Hypothesis 2 .

In order to test the influence of financial development on the R\&D investment of enterprises with different characteristics, the interaction term is introduced in Model 3 as follows.

$$
R D_{i t}=\beta_{0}+\beta_{1} F_{i N_{i t}}+\beta_{2} F C_{i t}+\beta_{3} \text { FIN }_{i t} \times \text { Dummy }_{i t}+\beta_{4} \text { Control }_{i t}+\varepsilon_{i t} \text {. (Model 3) }
$$

Dummy is a virtual variable of firm size, nature of ownership and establishment time. When sorted by firm size, the samples of enterprises in a given year are arranged according to the natural logarithm of total assets, which are divided into two groups of equal capacity. The values of large enterprises are 1 and small enterprises are 0 . When sorted by the nature of ownership, the values of state-owned enterprises are 1 and non-statedowned enterprises are 0 . When sorted by establishment time, the samples of enterprises in a given year are arranged according to the establishment time, which are divided into two groups. The values of long establishment time enterprises are 1 and short establishment time enterprises are 0 .

\section{Results and analysis}

\subsection{Descriptive statistics}

According to descriptive statistics shown in Table 4, the R\&D investment of strategic emerging industries is relatively high compared with other industries. According to the R\&D input intensity disclosed by "Science and technology funding statistics bulletin of 2017 in China", the manufacturing of railways, ships, aerospace and other transportation equipment have the highest R\&D investment intensity of $2.53 \%$. The sample enterprises have an average of $7.80 \%$, because of the tax relief and financial support provided by the governments to promote the innovation in recent years. The standard deviation of R\&D investment is 7.95, indicating that there are significant differences between different enterprises. The maximum and minimum values of FC index differ greatly, indicating that different enterprises are subject to different financing constraints. With the increase of capital required for enterprise development and 
the increasing investment in $\mathrm{R} \& \mathrm{D}$, the degree of financing constraints faced by strategic emerging industries has increased, as shown in Table 5.

Table 4. Results of descriptive statistics

\begin{tabular}{|l|c|c|c|c|c|}
\hline \multicolumn{1}{|c|}{ Index } & $\mathrm{N}$ & Minimum & Maximum & Average & $\begin{array}{c}\text { Standard } \\
\text { deviation }\end{array}$ \\
\hline $\begin{array}{l}\text { R\&D } \\
\text { investment } \\
\text { intensity }\end{array}$ & 1371 & 0.0200 & 58.25 & 7.7985 & 7.9516 \\
\hline FIN1 & 1371 & 0.1314 & 4.6882 & 1.5336 & 0.6230 \\
\hline FIN2 & 1371 & 0.0001 & 0.1748 & 0.0238 & 0.0257 \\
\hline FC & 1371 & -17.6575 & 10.0744 & -0.2141 & 2.0262 \\
\hline ROA & 1371 & -0.9650 & 0.3725 & 0.0642 & 0.0827 \\
\hline GROWTH & 1371 & -0.9818 & 10.0539 & 0.3163 & 0.5737 \\
\hline CAP & 1371 & 7.9728 & 17.6869 & 12.1770 & 1.1551 \\
\hline Q & 1371 & 0.8153 & 26.8177 & 2.6638 & 1.9534 \\
\hline SIZE & 1371 & 19.6985 & 26.4404 & 22.4329 & 1.2047 \\
\hline NAT & 1371 & 0.0000 & 1.0000 & 0.1800 & 0.3830 \\
\hline AGE & 1371 & 5.0000 & 38.0000 & 16.6600 & 5.1710 \\
\hline
\end{tabular}

Table 5. Financing constraint during 2010-2018

\begin{tabular}{|c|c|c|c|c|c|c|c|c|c|}
\hline & 2010 & 2011 & 2012 & 2013 & 2014 & 2015 & 2016 & 2017 & 2018 \\
\hline FC & -1.531 & -1.639 & -0.918 & -0.192 & -0.161 & 0.028 & -0.130 & 0.364 & 0.378 \\
\hline
\end{tabular}

By analyzing the R\&D investment of enterprises with different characteristics, Table 6 calculates the mean value of $R \& D$ investment of each group, and tests the difference between different groups. It can be seen that the R\&D investment of enterprises with different firm size, nature and establishment time varies greatly.

Table 6. Results of mean value test

\begin{tabular}{|l|c|c|l|c|c|c|}
\hline \multicolumn{1}{|c|}{$\begin{array}{c}\text { Sample } \\
\text { group }\end{array}$} & $\begin{array}{c}\text { Number of } \\
\text { samples }\end{array}$ & Mean & \multicolumn{1}{|c|}{$\begin{array}{c}\text { Sample } \\
\text { group }\end{array}$} & $\begin{array}{c}\text { Number of } \\
\text { samples }\end{array}$ & Mean & T-test \\
\hline $\begin{array}{l}\text { Large } \\
\text { enterprises }\end{array}$ & 686 & $5.86 \%$ & $\begin{array}{l}\text { Small } \\
\text { enterprises }\end{array}$ & 685 & $9.74 \%$ & $9.286^{* * *}$ \\
\hline State owned & 244 & $5.74 \%$ & $\begin{array}{l}\text { Non-stated } \\
\text { owned }\end{array}$ & 1127 & $8.25 \%$ & $6.184^{* * *}$ \\
\hline $\begin{array}{l}\text { Long } \\
\text { establish- } \\
\text { ment time }\end{array}$ & 648 & $6.63 \%$ & $\begin{array}{l}\text { Short } \\
\text { establishment } \\
\text { time }\end{array}$ & 723 & $8.85 \%$ & $5.277^{* * *}$ \\
\hline
\end{tabular}

Note: ${ }^{\star * *}$ stands for the level of 0.01 is significant. 


\subsection{Construction of financing constraint index}

According to the construction method of $\mathrm{KZ}$ index mentioned above, the ordered logistic regression results are shown in Table 7 . Therefore, the equation of calculating FC is:

$$
F C=-7.997 \times \frac{C F_{i t}}{A_{i t-1}}-35.199 \times \frac{D I V_{i t}}{A_{i t-1}}-2.338 \times \frac{C_{i t}}{A_{i t-1}}+3.564 L E V_{i t}+0.236 Q_{i t} .
$$

This conclusion is consistent with the symbol of coefficient obtained by Lamont, Polk \& Saaárequejo (2001), and enterprises with low operating cash flow, low cash holding, low cash dividend level, high asset-liability ratio and more investment opportunities face serious financing constraints.

Table 7. Results of ordered logistic regression

\begin{tabular}{|l|l|l|l|l|l|}
\hline & \multicolumn{1}{|c|}{$C F_{i t} / A_{i t-1}$} & \multicolumn{1}{c|}{$D I V_{i t} / A_{i t-1}$} & \multicolumn{1}{c|}{$C_{i t} / A_{i t-1}$} & \multicolumn{1}{c|}{$L E V_{i t}$} & \multicolumn{1}{c|}{$Q_{i t}$} \\
\hline \multirow{2}{*}{ Coefficient } & $-7.997^{* * *}$ & $-35.199^{* * *}$ & $-2.338^{* * *}$ & $3.564^{* * *}$ & $0.236^{* * *}$ \\
& $(-11.88)$ & $(-12.31)$ & $(-8.65)$ & $(11.58)$ & $(7.24)$ \\
\hline
\end{tabular}

Note: The values in parentheses are $\mathrm{T}$ value of the coefficient, ${ }^{* *}$ stands for the level of 0.01 is significant.

\subsection{Empirical analysis}

The empirical analysis is carried out by using multiple regression models, the results are shown in Table 8-11.

\subsubsection{Empirical analysis of Model 1}

Table 8 is the empirical results of Model 1 and 2. The second column is the regression result of the impact of financing constraint on $\mathrm{R} \& \mathrm{D}$ investment. The empirical results show that the regression coefficient of FC is -0.086 , and is significant at $1 \%$ level, indicating that there is a negative correlation between financing constraint and enterprise $\mathrm{R} \& \mathrm{D}$ investment. Hypothesis 1 is verified. Therefore, financing constraint is an important factor restricting $\mathrm{R} \& \mathrm{D}$ investment. In order to promote industrial development through innovation, it is necessary to reduce the degree of financing constraint faced by enterprises in $\mathrm{R} \& \mathrm{D}$ investment.

The coefficient of ROA is significantly negative at $1 \%$, which is contrary to the theoretical conclusion. Because it is generally believed that enterprises with strong profitability have more internal capital and face less financing constraints, so they can invest more in $\mathrm{R} \& \mathrm{D}$. However, the profitability of listed companies in strategic emerging industries is negatively correlated with their R\&D investment. This may be due to the strong support from local governments in recent years, so the listed companies of strategic emerging industries do not rely on internal funds for R\&D investment.

The coefficient of GROWTH is significantly negative at $1 \%$. In general, enterprises with good growth ability will inevitably increase the scale of long-term assets, and expenditures such as the expansion of fixed assets may crowd out the R\&D investment. 
Table 8. Results of Model 1 and 2

\begin{tabular}{|l|c|c|c|}
\hline \multicolumn{1}{|c|}{ RD } & Model 1 & Model 2(1) & Model 2(2) \\
\hline \multirow{2}{*}{ Constant term } & $3.584^{* * *}$ & $3.019^{* * *}$ & $\begin{array}{c}3.295^{* * *} \\
(5.186)\end{array}$ \\
\hline \multirow{2}{*}{ FIN1 } & $(5.642)$ & $0.146^{* * *}$ & $(3.567)$ \\
\hline \multirow{2}{*}{ FIN2 } & & & $4.127^{* * *}$ \\
& & & $(4.101)$ \\
\hline \multirow{2}{*}{ FC } & $-0.086^{* * *}$ & $-0.084^{* * *}$ & $-0.085^{* * *}$ \\
& $(-5.976)$ & $(-5.836)$ & $(-5.895)$ \\
\hline \multirow{2}{*}{ ROA } & $-1.282^{* * *}$ & $-1.245^{* * *}$ & $-1.214^{* * *}$ \\
& $(-3.607)$ & $(-3.517)$ & $(-3.431)$ \\
\hline \multirow{2}{*}{ GROWTH } & $-0.140^{* * *}$ & $-0.144^{* * *}$ & $-0.142^{* * *}$ \\
& $(-3.226)$ & $(-3.335)$ & $(-3.280)$ \\
\hline \multirow{2}{*}{ CAP } & $-0.218^{* * *}$ & $-0.203^{* * *}$ & $(-8.895)$ \\
\hline \multirow{2}{*}{ Q } & $(-9.653)$ & $(-8.928)$ & $0.098^{* * *}$ \\
& $0.099^{* * *}$ & $0.099^{* * *}$ & $(6.479)$ \\
\hline \multirow{2}{*}{ SIZE } & $(6.551)$ & $(6.522)$ & $-0.156^{* * *}$ \\
& $-0.154^{* * *}$ & $-0.150^{* * *}$ & $(-5.638)$ \\
\hline \multirow{2}{*}{ NAT } & $(-5.525)$ & $(-5.414)$ & $-0.205^{* * *}$ \\
\hline \multirow{2}{*}{ AGE } & $-0.204^{* * *}$ & $-0.204^{* * *}$ & $(-3.099)$ \\
\hline YEAR & $(-3.067)$ & $(-3.081)$ & $-0.010^{*}$ \\
\hline Adjusted R Squared & $-0.013^{* *}$ & $-0.010^{*}$ & $(-1.878)$ \\
\hline Prob>F & $(-2.306)$ & $(-1.733)$ & Controled \\
\hline
\end{tabular}

Note: ${ }^{* * *}$ stands for the level of 0.01 is significant; ${ }^{* *}$ stands for the level of 0.05 is significant; ${ }^{*}$ stands for the level of 0.1 is significant.

The coefficient of CAP is significantly negative at $1 \%$, which means that enterprises with higher capital-intensity are more likely to rely on capital investment rather than technology.

The regression coefficient of $\mathrm{Q}$ is 0.099 , and it is significant at the level of $1 \%$, which indicates that there is a positive relationship between investment opportunity and R\&D investment of enterprises. When making R\&D decisions, enterprises will consider the impact of investment opportunity on their R\&D investment.

The regression coefficient of SIZE is -0.154 , and it is significant at $1 \%$ level. The larger the enterprise, the more reluctant it is to invest in $\mathrm{R} \& \mathrm{D}$ for the sake of risk aversion. And for small enterprises, in order to survive and occupy the market, these enterprises must enhance investment in $\mathrm{R} \& \mathrm{D}$, the technology of products as well as production efficiency, so their enthusiasm for $\mathrm{R} \& \mathrm{D}$ is higher than large enterprises.

The regression coefficient of NAT is -0.204 , and it is significant at the level of $1 \%$. State-owned enterprises are more affected by the government's intervention, and their 
production and operation are more cautious. They usually maintain a relatively stable investment in $\mathrm{R} \& \mathrm{D}$, and they are not willing to take greater risks.

The regression coefficient of AGE is -0.013 , and it is significant at the level of $5 \%$. This shows that the establishment years of enterprises are negatively correlated with their R\&D investment. Enterprises with a long establishment year tend to stick to the established rules and are unwilling to take risks, which inhibits their R\&D investment.

\subsubsection{Empirical analysis of Model 2}

The third and fourth columns in Table 8 are the results of Model 2. Compared with Model 1, the coefficient and significance of control variables have not changed significantly after adding financial development variables, which indicates that financial development is exogenous for an enterprise. The adjusted $\mathrm{R}$ squared of model 2 has been improved, indicating that financial development plays an important role in enterprises' $R \& D$ investment. The improvement of financial development level will increase the number of financial institutions, expand the scale, diversify financial instruments, and make the financial market more developed, which is conducive to easing $\mathrm{R} \& \mathrm{D}$ financing constraint.

To be specific, the coefficient of financial intermediary development is 0.146 , and is significant at $1 \%$ level. Therefore, the impact of financial intermediary development on enterprise $R \& D$ investment cannot be ignored. The coefficient of stock market development is 4.127 , and is significant at $1 \%$ level, which shows that the development of stock market plays a positive role in enterprise $R \& D$ investment and a greater role than financial intermediary. This may be due to the high risk of R\&D and the huge difficulty to get bank loans to support investment in $\mathrm{R} \& \mathrm{D}$. As a result, the enterprises are more likely to get financial support from the stock market.

All in all, both the financial intermediary and the stock market are conducive to enterprises' R\&D investment, and the level of financial development is significantly positively correlated with $\mathrm{R} \& \mathrm{D}$ investment. Hypothesis 2 is verified. Therefore, in addition to the enterprise's own factors, such as profitability and growth, the financial environment of an enterprise also has an important impact on the enterprise's R\&D investment. The government should take active measures to improve local financial development level and create a good external environment for enterprises' innovation.

\subsubsection{Empirical analysis of Model 3}

Table 9-11 is the empirical results of Model 3. Based on model 2, interaction term is introduced to analyze the impact of financial development on R\&D investment for enterprises with different characteristics.

Table 9 displays the results of interaction term of FIN and SIZE. The coefficient of FIN $1{ }^{\star}$ SIZE is negative and significant at $1 \%$ level, and the coefficient of FIN $2^{\star}$ SIZE is negative and significant at 5\% level. This means compared with large enterprises, financial development plays a more significant role in $\mathrm{R} \& \mathrm{D}$ investment of small enterprises. This may be because larger enterprises have more sufficient cash flow and easier access to bank credit funds, and thus have lower financing constraints. In comparison, small enterprises are in the development stage and need a large amount of capital investment, but it is difficult for 
them to obtain credit funds due to their insufficient strength, so they face higher financing constraints. The financial environment level is more conducive to easing the R\&D investment of smaller enterprises and promoting the growth of their R\&D investment.

Table 9. Results of Model 3(1)

\begin{tabular}{|c|c|c|}
\hline $\mathrm{RD}$ & \multicolumn{2}{|c|}{ FIN-SIZE interaction } \\
\hline Constant term & $\begin{array}{l}1.460^{*} \\
(1.836)\end{array}$ & $\begin{array}{c}2.664^{* * *} \\
(3.858)\end{array}$ \\
\hline FIN1 & $\begin{array}{c}0.206^{* * *} \\
(4.625)\end{array}$ & \\
\hline FIN2 & & $\begin{array}{c}5.769^{* * *} \\
(4.694)\end{array}$ \\
\hline $\mathrm{FC}$ & $\begin{array}{c}-0.083^{* * *} \\
(-5.802)\end{array}$ & $\begin{array}{c}-0.083^{\star * *} \\
(-5.806)\end{array}$ \\
\hline ROA & $\begin{array}{c}-1.199 * * * \\
(-3.396)\end{array}$ & $\begin{array}{c}-1.133^{\star * *} \\
(-3.194)\end{array}$ \\
\hline GROWTH & $\begin{array}{c}-0.136^{* * *} \\
(-3.146)\end{array}$ & $\begin{array}{c}-0.139^{* * *} \\
(-3.216)\end{array}$ \\
\hline CAP & $\begin{array}{c}-0.201^{* * *} \\
(-8.872)\end{array}$ & $\begin{array}{c}-0.201^{* * *} \\
(-8.868) \\
\end{array}$ \\
\hline Q & $\begin{array}{c}0.097^{* * *} \\
(6.404)\end{array}$ & $\begin{array}{c}0.097^{* * *} \\
(6.400)\end{array}$ \\
\hline SIZE & $\begin{array}{l}-0.083^{* *} \\
(-2.454)\end{array}$ & $\begin{array}{c}-0.129^{* * *} \\
(-4.311)\end{array}$ \\
\hline FIN $1{ }^{\star}$ SIZE & $\begin{array}{c}-0.132^{* * *} \\
(-3.394)\end{array}$ & \\
\hline FIN $2 *$ SIZE & & $\begin{array}{l}-3.623^{* *} \\
(-2.320)\end{array}$ \\
\hline NAT & $\begin{array}{c}-0.200^{* * *} \\
(-3.034) \\
\end{array}$ & $\begin{array}{c}-0.208^{* * *} \\
(-3.143) \\
\end{array}$ \\
\hline AGE & $\begin{array}{l}-0.010^{* *} \\
(-1.849) \\
\end{array}$ & $\begin{array}{l}-0.011^{\star} \\
(-1.928) \\
\end{array}$ \\
\hline YEAR & Controled & Controled \\
\hline Adjusted R Squared & 0.239 & 0.238 \\
\hline Prob $>F$ & 0.000 & 0.000 \\
\hline
\end{tabular}

Note: ${ }^{* *}$ stands for the level of 0.01 is significant; ${ }^{* *}$ stands for the level of 0.05 is significant; ${ }^{*}$ stands for the level of 0.1 is significant.

Table 10 shows the results of interaction term of FIN and NAT. The coefficient of FIN $1{ }^{\star}$ NAT and FIN $2{ }^{\star}$ NAT is both negative and insignificant. It indicates that for strategic emerging industries, financial development (including financial intermediary and stock market) has no significant difference in alleviating financing constraints of R\&D investment between state-owned enterprises and non-state-owned enterprises. In recent years, in order to promote the development of strategic emerging industries, the Chinese 
government has increased financial and taxation support, including vigorously promoting the construction of emerging industries development funds, venture capital funds and state financing guarantee funds at various levels and with multiple entities. Moreover, the Chinese government also strengthens cooperation between the government and the bank, timely revises the catalogue of strategic emerging industries, and establishes a white list of leading enterprises in strategic emerging industries and a database of high-quality and fast-growing small and medium-sized enterprises. Therefore, both state-owned enterprises and non-state-owned enterprises benefit from the financial and fiscal policies supported by the government. In other industries, the more favorable role of financial development in relieving the financing constraints of non-state-owned enterprises has not been fully reflected in the strategic emerging industries.

Table 10. Results of Model 3(2)

\begin{tabular}{|c|c|c|}
\hline $\mathrm{RD}$ & \multicolumn{2}{|c|}{ FIN-NAT interaction } \\
\hline Constant term & $\begin{array}{c}2.900^{\star * *} \\
(4.410)\end{array}$ & $\begin{array}{c}3.286^{* * *} \\
(5.171)\end{array}$ \\
\hline FIN1 & $\begin{array}{c}0.173^{\star * *} \\
(3.804)\end{array}$ & \\
\hline FIN2 & & $\begin{array}{c}4.601^{\star * *} \\
(4.179)\end{array}$ \\
\hline FC & $\begin{array}{c}-0.085^{\star * *} \\
(-5.864)\end{array}$ & $\begin{array}{c}-0.085^{\star * *} \\
(-5.914)\end{array}$ \\
\hline ROA & $\begin{array}{c}-1.244^{\star * *} \\
(-3.514)\end{array}$ & $\begin{array}{c}-1.211^{\star * *} \\
(-3.423)\end{array}$ \\
\hline GROWTH & $\begin{array}{c}-0.146^{* * *} \\
(-3.370)\end{array}$ & $\begin{array}{c}-0.143^{* * *} \\
(-3.302)\end{array}$ \\
\hline CAP & $\begin{array}{c}-0.200^{* * *} \\
(-8.699)\end{array}$ & $\begin{array}{c}-0.200^{* * *} \\
(-8.734)\end{array}$ \\
\hline Q & $\begin{array}{c}0.099^{* * *} \\
(6.554)\end{array}$ & $\begin{array}{c}0.098^{\star * *} \\
(6.494)\end{array}$ \\
\hline SIZE & $\begin{array}{c}-0.149^{* * *} \\
(-5.353)\end{array}$ & $\begin{array}{c}-0.157^{\star * *} \\
(-5.678)\end{array}$ \\
\hline NAT & $\begin{array}{c}-0.002 \\
(-0.010)\end{array}$ & $\begin{array}{l}-0.145^{\star} \\
(-1.664)\end{array}$ \\
\hline FIN1*NAT & $\begin{array}{c}-0.137 \\
(-1.355)\end{array}$ & \\
\hline $\mathrm{FIN} 2^{\star} \mathrm{NAT}$ & & $\begin{array}{c}-2.661 \\
(-1.061)\end{array}$ \\
\hline AGE & $\begin{array}{l}-0.010^{\star} \\
(-1.804)\end{array}$ & $\begin{array}{l}-0.011^{\star} \\
(-1.921)\end{array}$ \\
\hline YEAR & Controled & Controled \\
\hline Adjusted R Squared & 0.233 & 0.235 \\
\hline Prob $>F$ & 0.000 & 0.000 \\
\hline
\end{tabular}

Note: ${ }^{* *}$ stands for the level of 0.01 is significant; ${ }^{* *}$ stands for the level of 0.05 is significant; ${ }^{*}$ stands for the level of 0.1 is significant. 
Table 11 is the results of interaction term of FIN and AGE. The coefficient of FIN $1^{\star}$ AGE is negative and significant at $5 \%$ level, and FIN2*AGE does not pass the significance test. This means compared with long establishment time enterprises, financial intermediary development plays a more significant role in $\mathrm{R} \& \mathrm{D}$ investment of short establishment enterprises. This is because the enterprises with long establishment time have established long-term cooperative relations with banks and their development is relatively stable, so they are less affected by financing constraints. The role of stock market development is not obvious. The stock market has a high requirement on information disclosure and information asymmetry is alleviated to some extent. Therefore, there is no significant difference in relieving financing constraints for enterprises with different establishment time.

Table 11. Results of Model 3(3)

\begin{tabular}{|c|c|c|}
\hline $\mathrm{RD}$ & \multicolumn{2}{|c|}{ FIN-AGE interaction } \\
\hline Constant term & $\begin{array}{l}2.641^{* *} \\
(3.995)\end{array}$ & $\begin{array}{c}3.255^{* * *} \\
(5.057)\end{array}$ \\
\hline FIN1 & $\begin{array}{c}0.197^{\star \star \star} \\
(4.484)\end{array}$ & \\
\hline FIN2 & & $\begin{array}{c}4.376^{\star * *} \\
(3.702)\end{array}$ \\
\hline $\mathrm{FC}$ & $\begin{array}{c}-0.083^{* * *} \\
(-5.780)\end{array}$ & $\begin{array}{c}-0.085^{* * *} \\
(-5.893)\end{array}$ \\
\hline ROA & $\begin{array}{c}-1.234^{* * *} \\
(-3.498)\end{array}$ & $\begin{array}{c}-1.206^{\star * *} \\
(-3.402)\end{array}$ \\
\hline GROWTH & $\begin{array}{c}-0.143^{* * *} \\
(-3.321)\end{array}$ & $\begin{array}{c}-0.142^{* * *} \\
(-3.277)\end{array}$ \\
\hline CAP & $\begin{array}{c}-0.203^{* * *} \\
(-8.926)\end{array}$ & $\begin{array}{c}-0.202^{\star * *} \\
(-8.883)\end{array}$ \\
\hline Q & $\begin{array}{c}0.100^{* * *} \\
(6.628)\end{array}$ & $\begin{array}{c}0.098^{\star * *} \\
(6.488)\end{array}$ \\
\hline SIZE & $\begin{array}{c}-0.148^{* * *} \\
(-5.334)\end{array}$ & $\begin{array}{c}-0.156^{\star * *} \\
(-5.607)\end{array}$ \\
\hline NAT & $\begin{array}{c}-0.231^{* * *} \\
(-3.468)\end{array}$ & $\begin{array}{c}-0.209^{* * *} \\
(-3.124)\end{array}$ \\
\hline AGE & $\begin{array}{c}0.006 \\
(0.861)\end{array}$ & $\begin{array}{c}-0.009 \\
(-1.455)\end{array}$ \\
\hline FIN1*AGE & $\begin{array}{c}-0.130^{* * *} \\
(-3.137)\end{array}$ & \\
\hline FIN2*AGE & & $\begin{array}{c}-0.671 \\
(-0.402)\end{array}$ \\
\hline YEAR & Controled & Controled \\
\hline Adjusted R Squared & 0.238 & 0.235 \\
\hline Prob $>F$ & 0.000 & 0.000 \\
\hline
\end{tabular}

Note: ${ }^{* *}$ stands for the level of 0.01 is significant; ${ }^{* *}$ stands for the level of 0.05 is significant; ${ }^{*}$ stands for the level of 0.1 is significant. 
The coefficients and significance of other independent variables and control variables did not change significantly in Model 3 compared to Model 2.

In conclusion, both the development of financial intermediaries and stock market play a more significant role in easing financing constraints on R\&D investment of small enterprises. And financial development (including financial intermediary and stock market) has no significant difference in alleviating financing constraints of R\&D investment between stateowned enterprises and non-state-owned enterprises. And financial intermediary development plays a more significant role in alleviating financing constraints of $R \& D$ investment of short-established enterprises compared to long-established enterprises, while the role of stock market development is not obvious. Hypothesis 3 is partly verified. To be specific, for enterprises of different sizes, nature and time of establishment, they should take different measures to reduce the degree of information asymmetry, and the government should also help them increase $\mathrm{R} \& \mathrm{D}$ investment by giving full play to the role of financial intermediary and stock market. In particular, the multi-tiered capital market should be improved.

\section{Conclusions}

This paper takes listed companies of strategic emerging industries as the research subject, and studies the relationship among financial development, financing constraints and enterprises' R\&D investment. The main conclusions are as follows: (1) The degree of financing constraints faced by enterprises of strategic emerging industries has increased during 2010-2018. And the degree of financing constraint is negatively correlated with R\&D investment. (2) Both the development of financial intermediary and stock market plays an important role in alleviating the financing constraints and provide the enterprises with sufficient R\&D investment. And the development of stock market plays a greater role compared to financing intermediaries. (3) Both the development of financial intermediaries and stock market play a more significant role in easing financing constraints on R\&D investment of small enterprises. (4) The financial development (including financial intermediary and stock market) has no significant difference in alleviating financing constraints of R\&D investment between state-owned enterprises and non-state-owned enterprises. (5) The financial intermediary development plays a more significant role in alleviating financing constraints of R\&D investment of short-established enterprises compared to long-established enterprises, while the role of stock market development is not obvious.

Based on the theoretical and empirical research, the following suggestions are proposed. (1) The government should take measures to improve the local financial development level. First, the government should continue to provide financial support for R\&D investment in strategic emerging industries, including tax reduction and exemption, finance discount, preferential interest rate, and so on. Second, the scale of scientific and technological finance should be expanded. On the one hand, the government should increase the number of regional venture capital institutions and expand their scale. Regional commercial banks should also be encouraged to actively issue science and technology loans and increase financial support for enterprises of strategic emerging industries. On the other hand, the government should promote outstanding enterprises to go public. 
Shanghai Stock Exchange Technology and Innovation Board officially opened on June 13, 2019, focusing on supporting high-tech industries and strategic emerging industries. This is a good opportunity for strategic emerging industries. In addition, diversified financial products should be provided to meet the needs of strategic emerging industries. The government should encourage commercial banks and other financial institutions to conduct financial innovation for more $\mathrm{R} \& \mathrm{D}$ projects, promote diversified credit products and financial services to expand financing channels for R\&D activities, and facilitate the development of intermediary service institutions that provide guarantee for innovation. Third, the government should accelerate the development of the social credit system and create a good credit environment. And the credit reporting system for listed companies need to be further improved in order to reduce the information asymmetry between fund suppliers and enterprises. (2) The enterprises should attach importance to R\&D and constantly increase investment in R\&D. First, they should improve the operation and management ability so as to improve the efficiency of R\&D investment. Second, they should strengthen the credit awareness, attach importance to credit construction to improve their credit level, and establish a perfect information disclosure system to provide financial information. Third, they should maintain close cooperation with financial institutions to ease financing constraints resulted from the information asymmetry between fund suppliers and demanders.

Some innovations are applied in this study. First, the strategic emerging industries represent the direction of a new round of scientific and technological revolution and industrial transformation. They are key areas for cultivating and developing new drivers of growth and gaining new competitive advantages in China. And R\&D investment is the basis for scientific and technological innovation activities. Therefore, it is necessary to study the relationship among financing development, financing constraint and R\&D investment. Second, in the empirical study, this paper analyzes the impact of financial development on alleviating financing constraints and promoting R\&D investment from the perspectives of the financial intermediary and stock market. Third, this paper further analyzes the differences among enterprises with different sizes, ownership nature and time of establishment of the role of financial development in alleviating R\&D financing constraints. However, this study also has some limitations. First, due to limited sample data taken from Strategic Emerging Industries Index disclosed by Shenzhen Stock Exchange in China, a full sample of strategic emerging industries needs to be concluded in the future study. Second, this paper chooses $\mathrm{KZ}$ index as a measurement of financing constraint, and several other indexes can be selected for future research.

\section{Funding}

This work was supported by the National Social Science Foundation of China under Grant [No. 15BGL056]; Prospective Research Fund for Basic Research Costs in Central Universities under Grant [No. NW2019002]. 


\section{Author contributions}

$\mathrm{Ke} \mathrm{Xu}$ and Cheng-xuan Geng conceived the experiments. Ke Xu and Huifeng Jiang performed the experiments and analyzed the data. Xiaoshu Wei revised the English expression. All authors wrote the paper.

\section{Disclosure statement}

The authors declare that we have no competing financial, professional, or personal interests from other parties.

\section{References}

Alam, A., Uddin, M., \& Yazdifar, H. (2019). Financing behavior of R\&D investment in the emerging markets: The role of alliance and financial system. $R \& D$ Management, 49(1), 21-32. https://doi.org/10.1111/radm.12303

Almeida, H., Campello, M., \& Weisbach, M. S. (2004). The cash flow sensitivity of cash. Journal of Finance, 59(4), 1777-1804. https://doi.org/10.2139/ssrn.345840

Brown, J. R., Martinsson, G., \& Petersen, B. C. (2011). Do financing constraints matter for R\&D? European Economic Review, 56(8), 1512-1529. https://doi.org/10.2139/ssrn.1684731

Cao, X. F. (2014). Financing constraint and enterprise R\&D investment - an empirical study based on enterprise data. Soft Science, 28(12), 73-78. https://doi.org/10.3969/j.issn.1001-8409.2014.12.017

Chen, K., \& Chang, L. (2019). Research on the effectiveness of financing constraint measure of investment-cash flow sensitivity. Friends of Accounting, 23, 137-142. https://doi.org/10.3969/j.issn.1004-5937.2019.23.024

Chen, P., \& Yang, M. (2018). Research on the impact of financing constraints on R\&D investment of SMEs. Communication of Finance and Accounting, 26, 57-61. https://doi.org/10.16144/j.cnki.issn1002-8072.2018.26.014

Cheng, L., Wang, S., \& Liu, Q. (2019). An economic analysis of financing constraints and corporate R\&D manipulation. Finance \& Trade Economics, 40(8), 67-82. https://doi.org/10.19795/j.cnki.cn11-1166/f.20190806.010

Cleary, S. (1999). The relationship between firm investment and financial status. The Journal of Finance, 54(2), 673-692. https://doi.org/10.1111/0022-1082.00121

Dai, X. Y., \& Cheng, L. W. (2015). The influence mechanism of financial development on enterprise financing constraint and R\&D investment. R\&D Management, 27(3), 25-33. https://doi.org/10.3969/j.issn.1004-8308.2015.03.004

Farre-Mensa, J., \& Ljungqvist, A. (2016). Do measures of financial constraints measure financial constraints? Review of Financial Studies, 29(2), 271-308. https://doi.org/10.2139/ssrn.2338575

Fazzari, S. M., Hubbard, R. G., Petersen, B. C., Blinder, A. S., \& Poterba, J. M. (1988). Financing constraints and corporate investment. Brookings Papers on Economic Activity, 1988(1), 141-206. https://doi.org/10.2307/2534426

Geng, C. X., Li, M., \& Hai-tao, E. (2018). Financing efficiency and financing constraints of new energy enterprises - based on the empirical analysis of A share new energy listed companies in China. East China Economic Management, 1, 153-159. https://doi.org/10.19629/j.cnki.34-1014/f.170805001

Gu, Q., \& Zhai, S. P. (2014). Financial constraints, R\&D investment and funding sources: The perspective of R\&D heterogeneity. Science of Science and Management of S. \& T., 35(3), 15-22. 
Guariglia, A., \& Liu, P. (2014). To what extent do financing constraints affect Chinese firms' innovation activities? International Review of Financial Analysis, 36(C), 223-240.

https://doi.org/10.1016/j.irfa.2014.01.005

Hall, B. H., \& Lerner, J. (2010). The financing of R\&D and innovation. Handbook of the Economics of Innovation, 1, 609-639. https://doi.org/10.1016/S0169-7218(10)01014-2

$\mathrm{Hu}$, J., \& Qin, L. (2013). Research on the influence of financial development on the restriction of enterprise R\&D financing - empirical evidence from China's listed high-tech companies. Journal of Hebei University of Economics and Business, 34(5), 59-62. https://doi.org/10.3969/j.issn.1007-2101.2013.05.010

Hu, J., Li, G., \& Zhu, F. (2017) Regional financial developments and research and development investment-cash flow sensitivity: Evidence on Chinese public high-tech companies. International Review of Finance, 17, 627-642. https://doi.org/10.1111/irfi.12122

$\mathrm{Hu}$, Y. R., Chen, D. D., \& Liu, Z. (2018). Financing constraints, cyclical and smooth mechanism of enterprise R\&D investment -based on enterprise ownership perspective. Industrial Economics Research, 2, 78-90. https://doi.org/10.13269/j.cnki.ier.2018.02.007

Kaplan, S. N., \& Zingales, L. (1997). Do investment-cash flow sensitivities provide useful measures of financing constraints? Quarterly Journal of Economics, 112(1), 169-215. https://doi.org/10.1162/003355397555163

Kuang, X. W. (2011). Does financial development reduce the firm's financial constraints? East China Economic Management, 25(5), 74-79. https://doi.org/10.3969.j.issn.1007-5097.2011.05.017

Laeven, L. (2003). Does financial liberalization reduce financing constraints? Financial Management, 32(1), 5-34. https://doi.org/10.2307/3666202

Lamont, O., Polk, C., \& Saaárequejo, J. (2001) Financial constraints and stock returns. Review of Financial Studies, 14(2), 529-554. https://doi.org/10.1093/rfs/14.2.529

Li, Y., \& Zhang, T. (2009). Evaluation of financial ecological environment in China (2008-2009). China Finance Press.

Liu, H. D. (2014). Financial development, enterprise R\&D financing constraint ease and total factor productivity growth: Empirical evidence from China's industrial level. South China Finance, (1), 21-27. https://doi.org/10.3969/j.issn.1007-9041.2014.01.005

Liu, W. Q., He, Y. Q., \& Zheng, Y. (2018). Financial deepening, financing constraint and enterprise's R\&D investment - an analysis from the perspective of industry heterogeneity. Jiangxi Social Sciences, 38(12), 215-224.

Liu, Y. H. (2007). Evaluation of financial ecological environment in China (2006-2007). China Finance Press.

Liu, Y. H., \& Chen, X. S. (2011). Evaluation of financial ecological environment in China (2009-2010). Social sciences academic press, Beijing.

Love, I. (2003). Financial development and financing constraints: International evidence from the structural investment model. Review of Financial Studies, 16(3), 765-791. https://doi.org/10.1093/rfs/hhg013

Lu, X., Zheng, Y. F., \& Li, J. M. (2013). Research on the influence of financing constraints on enterprise R\&D investment - empirical evidence from China's listed high-tech companies. Accounting Research, 5, 51-58. https://doi.org/10.3969/j.issn.1003-2886.2013.05.007

Modigliani, F., \& Miller, M. H. (1958). The cost of capital, corporation finance and the theory of investment. The American Economic Review, 3, 261-297.

Sasidharan, S., Lukose, J., \& Komera, S. (2015). Financing constraints and investments in R\&D: Evidence from Indian manufacturing firms. The Quarterly Review of Economics and Finance, 55, 28-39. https://doi.org/10.1016/j.qref.2014.07.002 
Song, J. B., Su, Z. H., \& Nie, X. Q. (2018). Does development of financial markets help firm innovation? Evidence from China. Economic and Political Studies, 6(2), 194-208. https://doi.org/10.1080/20954816.2018.1463601

Wan, M. T. (2018). Empirical study on the relationship between financing constraints and R\&D investment - based on empirical data of GEM listed companies. Management and Administration, 412(10), 53-56. https://doi.org/10.16517/j.cnki.cn12-1034/f.2018.10.015

Wang, X. L., Fan, G., \& Yu, J. W. (2017). Report of market index of China's provinces (2016). Social Sciences Academic Press.

Wei, F., \& Liu, X. (2004). The impact of financing constraints, uncertainty on the corporate's investment behavior. Economic Science, 26(2), 35-43.

Wei, Y. D., \& Lan, Y. Z. (2019). Financial association and enterprise's financing contract. Communication of Finance and Accounting, 36, 96-102. https://doi.org/10.16144/j.cnki.issn1002-8072.2019.36.019

Wei, Z. H., Zeng, A. M., \& Li, B. (2014). Financial ecological environment and financing constraints based on empirical research on Chinese listed companies. Accounting Research, 5, 73-80. https://doi.org/10.3969/j.issn.1003-2886.2014.05.009

Whited, T. M., \& Wu, G. (2006). Financial constraints risk. Review of Financial Studies, 19(2), 531-559. https://doi.org/10.2139/ssrn.410816

$\mathrm{Wu}$, J. (2019). Financing constraints for R\&D in China: The role of state ownership. Applied Economics Letters, 26(14), 1162-1166. https://doi.org/10.1080/13504851.2018.1540839

Xie, W. M., \& Fang, H. X. (2011). Financial development, financing constraint and enterprises R\&D investment. Journal of Financial Research, 5, 171-183.

Yuan, L., \& Xu, T. (2019). Does the financing mode affect the technological innovation of enterprisesempirical evidence from the world bank's survey of Chinese enterprises. Journal of Macro-Quality Research, 7(3), 111-128. https://doi.org/10.13948/j.cnki.hgzlyj.2019.03.008

Zeng, Z. M., Wang, C. J., \& Zhang, Q. (2017). The influence of financial development on financing constraints of China's small and medium-sized listed companies. The Theory and Practice of Finance and Economics, 38(4), 15-20.

Zhai, S. P., \& Gu, Q. (2013). Research on financial development, financial constraint and investment efficiency of high-tech enterprises. Economic Survey, 2, 138-143. https://doi.org/10.3969/j.issn.1006-1096.2013.02.026

Zhang, H. Y., \& Wang, L. (2016). Financial development, financing constraints and the development of strategic emerging industries. Journal of Beijing Technology and Business University (Social Sciences), 1, 94-101. https://doi.org/10.16299/j.1009-6116.2016.01.011

Zhang, S. J. (2018). Research on the correlation between financing constraint and enterprise innovation input - from the perspective of combination of industry and finance. Communication of Finance and Accounting, 15, 109-113. https://doi.org/10.16144/j.cnki.issn1002-8072.2018.15.022

Zhu, D. P., \& Sun, L. L. (2015). Financing constraints, market environment and R\&D investment: an empirical research on listed companies of Chinese biological medicine industry. Science and Technology Management Research, 22, 98-102. https://doi.org/10.3969/j.issn.1000-7695.2015.22.019 